\title{
Mechanical Twinning in Copper-29.9 at.\% Gold Single Crystals
}

\author{
J. VAN DER PLANKEN, G. VAN DER PERRE, H. GOEMINNE \\ Instituut voor Metaalkunde, G. de Croylaan 2, 3030 Heverlee, Belgium
}

Three copper-gold single crystals containing 29.9 at. \% gold and having the disordered, $\mathrm{Cu}_{3} \mathrm{Au} \mathrm{I}$ and $\mathrm{Cu}_{3} \mathrm{Au}$ II structure respectively, were deformed in tension at room temperature, at dry ice temperature (just into the plastic region) and at liquid nitrogen temperature (until fracture) successively.

For $\mathrm{Cu}_{3} \mathrm{Au} \mathrm{I}$ and $\mathrm{Cu}_{3} \mathrm{Au}$ II $\tau_{\text {no }}$ does not vary practically with composition, being four times that of stoichiometric $\mathrm{Cu}_{3} \mathrm{Au}$ [6]. At $78^{\circ} \mathrm{K}$ twinning was observed in the elastic region for $\mathrm{Cu}_{3} \mathrm{Au} \mathrm{II}$, whereas $\mathrm{Cu}_{3} \mathrm{Au} I$ twinned only under the influence of complex stresses; the disordered alloy showed no twinning at all.

The strain-hardening $\theta_{\| 1}$ at $78^{\circ} \mathrm{K}$ is almost the same for $\mathrm{Cu}_{3} \mathrm{Au} \mathrm{I}$ and $\mathrm{Cu}_{3} \mathrm{Au} \|$ at the 20.9 at. $\%$ composition.

Twinning in pure metals and metallic solid solutions during mechanical testing is normally accompanied by audible clicks and load drops on the stress-strain curve. On the other hand the occurrence of these phenomena does not necessarily imply that twinning has taken place, e.g. in ordered structures, in which the condition that the twinned portion of the crystal is a mirror image of the parent crystal cannot be fulfilled. The question as to whether the term twin may be used in this case has given rise to some discussion $[1,2]$. In 1952 Laves [3] predicted that mechanical twinning in ordered cubic crystals is not possible and he proposed [1] that the word "pseudo-twin" should be used, e.g. for the stressinduced shear process occurring in $\mathrm{Fe}_{3} \mathrm{Be}$ [4]. Despite the difference between the classical mechanical twins and the twin-like behaviour of superlattices the term twinning has been employed for treating twin-like phenomena in ordered structures [5]. No other word will be adopted here for describing the deformation characteristics in $\mathrm{Cu}_{3} \mathrm{Au} \mathrm{I}$ and $\mathrm{Cu}_{3} \mathrm{Au}$ II structures of the copper-29.9 at. \% gold alloy, resembling twinning.

A copper-gold single crystal containing 29.9 at. $\%$ gold (further indicated as $\mathrm{Cu}_{70} \mathrm{Au}_{30}$ ) of $4 \mathrm{~mm}$ diameter was prepared in a vacuum-sealed $\left(10^{-5}\right.$ torr) quartz tube by a modified Bridgman technique. The growth speed was $4 \mathrm{~cm} \mathrm{~h}^{-1}$ and 492 the furnace temperature gradient amounted to about $50^{\circ} \mathrm{C} \mathrm{cm}^{-1}$. The crystal was easily removed from the mould, electropolished in a solution of chromic acetic acid and its singleness checked with Laue back-reflection photographs.

Subsequently the single crystal was spark-cut into three tensile specimens which had the disordered, the $\mathrm{Cu}_{3} \mathrm{Au} \mathrm{I}$ and the $\mathrm{Cu}_{3} \mathrm{Au}$ II structure respectively.

TA B LE I Heat-treatments required for obtaining the structures indicated

\begin{tabular}{ll}
\hline Structure & Heat-treatment \\
\hline Disordered & water-quenched from $400^{\circ} \mathrm{C}$ \\
$\mathrm{Cu}_{3} \mathrm{Au} \mathrm{I}$ & 16 days at $300^{\circ} \mathrm{C}$; water quenched \\
$\mathrm{Cu}_{3} \mathrm{Au} \mathrm{II}$ & 7 days at $340^{\circ} \mathrm{C}$; water-quenched \\
\hline
\end{tabular}

The applied heat treatments are given in table I. The $\mathrm{Cu}_{3} \mathrm{Au}$ II structure was checked by a rotating crystal X-ray diffraction photograph and the orientation of the single crystals determined by the back-reflection Laue technique.

Each specimen was then tested in tension at three different temperatures as follows: first, deformed until the end of the elastic region at room temperature, the load was removed and the sample was cooled in crushed dry ice; deformed again at this temperature just into the plastic

(C) 1970 Chapman and Hall Ltd. 
region; finally the sample was deformed until fracture in liquid nitrogen.

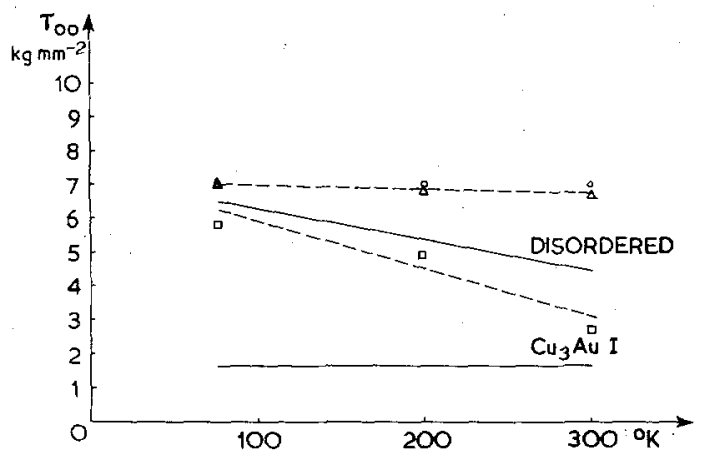

Figure 1 Variation of $\tau_{00}$, determined at the first noticeable departure from the elastic slope, with temperature for a copper 29.9 at. \% gold alloy having the disordered, the $\mathrm{Cu}_{3} \mathrm{Au} \mathrm{I}$ and $\mathrm{Cu}_{3} \mathrm{Au}$ II structures. $\square$, disordered; $\triangle$, $\mathrm{Cu}_{3} \mathrm{Au}$ I; $\mathrm{O}, \mathrm{Cu}_{3} \mathrm{Au} \mathrm{II}$, present work, $\tau_{00}, \mathrm{Cu}_{70} \mathrm{Au}_{30}$ composition. -, Davies and Stoloff [6], $\tau_{0}, \mathrm{Cu}_{3} \mathrm{Au}$ composition included for comparison.

The change of $\tau_{00} *$ versus temperature is plotted in fig. 1; the results of Davies and Stoloff [6] for the critical resolved shear stress $\tau_{0}$ have been included for comparison. Fig. 2 gives the shear stress-shear strain curves at $78^{\circ} \mathrm{K}$ for the three structures together with their orientation.

The strain-hardening in the second part of the shear stress-shear strain curve $\theta_{\mathrm{II}}$ at $78^{\circ} \mathrm{K}$ for the three structures is given in table II.

At point $\mathrm{P}$ of the shear stress-shear strain curve (fig. 2) for $\mathrm{Cu}_{3} \mathrm{Au}$ I the test was interrupted, the specimen was remounted, the stress axis being non-coincident with the specimen axis and the test continued at $78^{\circ} \mathrm{K}$. This mounting probably will cause complex stresses and facilitate twinning in an analogous way to pre-straining $90^{\circ}$ to the stress axis [8].

Fig. 3 represents the as-recorded loadelongation diagram and displays numerous load

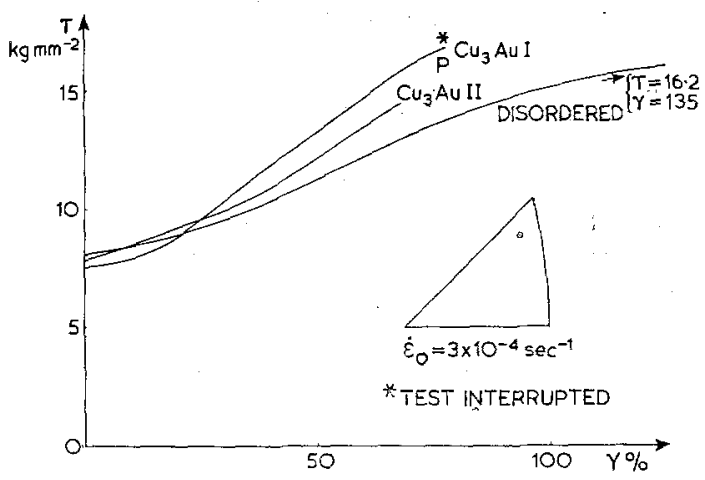

Figure 2 Shear stress-shear strain curves of copper29.9 at. \% gold crystals in the disordered condition and having the $\mathrm{Cu}_{3} \mathrm{Au} \mathrm{I}$ and $\mathrm{Cu}_{3} \mathrm{Au}$ II structures.

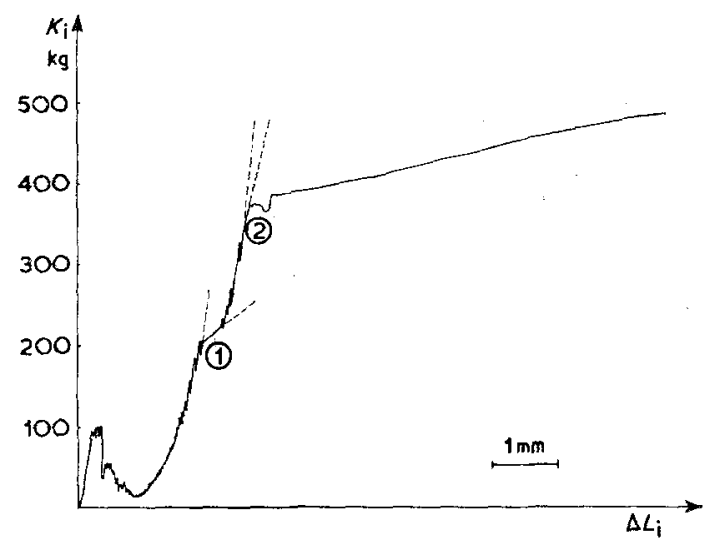

Figure 3 Load-elongation curve of $\mathrm{Cu}_{3} \mathrm{Au}$ I showing serrations due to twinning. 1 , lowering the strain rate to $3.5 \times 10^{-5} \mathrm{sec}^{-1} .2$, increasing the temperature.

drops, normally indicative of twinning. The twinning, accompanied by crackling sounds, started at a shear stress of about $2.8 \mathrm{~kg} \mathrm{~mm}^{-2}$.

Decreasing the strain rate or increasing the temperature for a short time during the test stopped the twinning and the strain-hardening associated with the glide decreased (fig. 3). Re-

TABLE II Strain hardening $\theta_{||}$for $\mathrm{Cu}_{3} \mathrm{Au}$ at $78^{\circ} \mathrm{K}$

\begin{tabular}{|c|c|c|c|c|}
\hline \multirow{2}{*}{$\begin{array}{l}\text { Composition } \\
\text { Structure }\end{array}$} & \multicolumn{2}{|l|}{$\mathrm{Cu}_{20} \mathrm{Au}_{30}$} & \multicolumn{2}{|c|}{$\begin{array}{l}\mathrm{Cu}_{3} \mathrm{Au} \\
\text { Davies and Stoloff [6] }\end{array}$} \\
\hline & $\begin{array}{l}\theta_{\mathrm{II}} \\
\left(\mathrm{g} \mathrm{mm}^{-2}\right)\end{array}$ & $\left(\theta_{\Pi \amalg} / G^{\dagger}\right) \times 10^{3}$ & $\begin{array}{l}\theta_{\mathrm{II}} \\
\left(\mathrm{g} \mathrm{mm}^{-2}\right)\end{array}$ & $\left(\theta_{\mathrm{II}} / G^{\dagger}\right) \times 10^{3}$ \\
\hline Disordered & 10049 & 2.21 & 10488 & 2.30 \\
\hline $\mathrm{Cu}_{3} \mathrm{Au} \mathrm{I}$ & 14416 & 3.11 & 10254 & 2.21 \\
\hline $\mathrm{Cu}_{3} \mathrm{Au} \mathrm{II}$ & 13560 & - & 一 & - \\
\hline
\end{tabular}

${ }^{*} \tau_{0 j}$ is the shear stress on the primary glide system at the first perceptible departure from the elastic part. $\dagger G=\left[\mathrm{C}_{44}\left(\mathrm{C}_{11}-\mathrm{C}_{12}\right) / 2\right]^{1 / 2}$ from the work of Flinn, McManus and Rayne [7]. 
straining at the original conditions made twinning reappear.

The specimen, having the $\mathrm{Cu}_{3} \mathrm{Au}$ II structure, was tested in the normal way at $78^{\circ} \mathrm{K}$ and twinned easily in the elastic region at about the same shear stress (i.e. $2.6 \mathrm{~kg} \mathrm{~mm}^{-2}$ ) as the $\mathrm{Cu}_{3} \mathrm{Au} \mathrm{I}$ structure. However, only five clicks were heard in the elastic region and no loaddrops could be detected on the curve. During the plastic deformation twinning sounds were observed from time to time but no load-falls accompanied these events. In the specimen with the disordered structure no twinning occurred at all.

Summarising we can say:

(i) The temperature-dependence of the critical resolved shear stress for $\mathrm{Cu}_{3} \mathrm{Au}$ crystals [6] appears to be the same as for $\mathrm{Cu}_{70} \mathrm{Au}_{30}$ crystals (this work) both in the disordered and in the $\mathrm{Cu}_{3} \mathrm{Au} \mathrm{I}$ condition. However, the slope of the line for the disordered structure is steeper for the $\mathrm{Cu}_{70} \mathrm{Au}_{30}$ than for the $\mathrm{Cu}_{3} \mathrm{Au}$ crystals and the non-stoichiometric $\mathrm{Cu}_{3} \mathrm{Au}$ I structure is about four times stronger than the stoichiometric structure.

The first difference may perhaps be approached by considering the excess gold atoms as solute atoms in a "pure" structure $\mathrm{Cu}_{3} \mathrm{Au} \mathrm{I}$ and producing an analogous effect as solute in a pure metal. The increase of yield stress, due to deviations from stoichiometry, has been reported earlier [9] for polycrystalline copper-gold alloys. (ii) $\tau_{00}$ of the $\mathrm{Cu}_{3} \mathrm{Au}$ II structure in $\mathrm{Cu}_{70} \mathrm{Au}_{30}$ does not vary with temperature and is almost the same as for the $\mathrm{Cu}_{3} \mathrm{Au}$ I structure of the same composition.

(iii) The strain-hardening $\theta_{\mathrm{II}}$ at $78^{\circ} \mathrm{K}$ for the disordered structure is nearly the same for the $\mathrm{Cu}_{3} \mathrm{Au}$ and for the $\mathrm{Cu}_{70} \mathrm{Au}_{30}$ compositions (table $\Pi$ ). For the $\mathrm{Cu}_{3} \mathrm{Au} \mathrm{I}$ structure it is about
$40 \%$ higher for the $\mathrm{Cu}_{70} \mathrm{Au}_{30}$ than for the $\mathrm{Cu}_{3} \mathrm{Au}$ alloy in a similar structure. The $\mathrm{Cu}_{3} \mathrm{Au}$ II structure has approximately the same $\theta_{\mathrm{II}}$ as the $\mathrm{Cu}_{3} \mathrm{Au}$ I structure for the $\mathrm{Cu}_{70} \mathrm{Au}_{30}$ composition. (iv) Twinning in $\mathrm{Cu}_{3} \mathrm{Au} \mathrm{I}$ has not been observed for the $\mathrm{Cu}_{3} \mathrm{Au}$ alloy [6]. It occurred in the $\mathrm{Cu}_{70} \mathrm{Au}_{30}$ alloy having the same structure, though the stresses needed for it are probably high. In the present work twinning could be produced at $78^{\circ} \mathrm{K}$ under the influence of complex stresses.

(v) $\mathrm{Cu}_{3} \mathrm{Au} \mathrm{II}$ was observed to twin at $78^{\circ} \mathrm{K}$ and for the $\mathrm{Cu}_{70} \mathrm{Au}_{30}$ composition, but the twins were very fine (they did not produce any observable load-drop and could only be heard), and relatively scarce.

The two last points may indicate that twin nucleation is favoured by deviations from stoichiometry.

(vi) No twinning was observed in the disordered $\mathrm{Cu}_{70} \mathrm{Au}_{30}$ alloy.

\section{References}

1. F. LAVES, Acta Met. 14 (1966) 58.

2. G. F. BOLLING and R. H. RICHMAN, ibid 14 (1966) 58.

3. F. LAVES, Naturwissenschaften 39 (1952) 546.

4. G. F. Bolling and R. H. RICHMAN, Acta Met. 13 (1965) 709 .

5. N. S. Stoloff and R. G. Davies, Prog. Mat. Sci. 13 (1966) $n^{0} 1$.

6. R. G. DAvies and N. s. Stoloff, Phil. Mag. 12 (1965) 297.

7. P. A. FLINN, G. M. MCMANUS, and J. A. RAYNE, J. Phys. Chem. Solids 15 (1960) 189.

8. G. F. BOLling and R. H. Richman, Can.J. Phys. 45 (1967) 541.

9. V. I. SYUTKINA and E. S. YAKOVLEVA, Sov. Phys. Solid State 4 (1963) 2125 (ref. taken from [6]).

Received 20 February and accepted 13 March 1970. 